\title{
Maintenance of Hokkien Language by Its Speakers in Medan
}

\author{
Linda Wijaya ${ }^{1}$, Amrin Saragih ${ }^{2}$, Zainuddin ${ }^{3}$ \\ ${ }^{1,2,3}$ English Applied Linguistic Study Program, Postgraduate School, State University of Medan
}

\begin{tabular}{|c|c|}
\hline ARTICLE INFO & ABSTRACT \\
\hline $\begin{array}{l}\text { Article history: } \\
\text { Received Feb 26, } 2019 \\
\text { Revised Jun 10, } 2019 \\
\text { Accepted Sep 27, } 2019\end{array}$ & $\begin{array}{l}\text { Indonesia is famous for various culture that attracts many tourists } \\
\text { from several part of the world to have a visit. Besides having } \\
\text { numerous culture, Indonesia is flourished with different ethnics, too, } \\
\text { such as the Javanese, the Bataknese, the Indian and the Chinese. } \\
\text { Every ethnic speak with different language, but formally the national }\end{array}$ \\
\hline $\begin{array}{l}\text { Keywords: } \\
\text { Hokkien Language, } \\
\text { Language Maintenance, } \\
\text { Hokkien Speakers }\end{array}$ & $\begin{array}{l}\text { derives from Chinese ethnic and resides in Medan, has taken interest } \\
\text { in preserving her mother tongue which is Hokkien language. Hokkien } \\
\text { language is an informal language which is used by the Hokkien } \\
\text { speakers to communicate with one another. In maintaining language, } \\
\text { the researcher focuses on the phenomena that happens lately, the } \\
\text { researcher feels that Hokkien language is not important for some of } \\
\text { the young family in Medan, they teach their children the other }\end{array}$ \\
\hline $\begin{array}{l}\text { Clonflict of Interest: } \\
\text { None }\end{array}$ & $\begin{array}{l}\text { language that develops immensely throughout people life. Even } \\
\text { though some still maintain Hokkien language, the researcher feels } \\
\text { that children do not put any interest in speaking their mother tongue. }\end{array}$ \\
\hline $\begin{array}{l}\text { Funding: } \\
\text { None }\end{array}$ & $\begin{array}{l}\text { problem in this study is concerned with factors influencing the } \\
\text { preservation of Hokkien language. The presentation of the data } \\
\text { described in qualitative descriptive method and this study conducted } \\
\text { through field survey with interviews and observation. The findings } \\
\text { revealed that there are two kinds of language maintenance between } \\
\text { young speakers and old speakers. The former has lesser effort in } \\
\text { maintaining the language, while the latter has stronger effort. Despite } \\
\text { the difference, all of Hokkien speakers still make use of the language } \\
\text { in their daily activities. Other factors are the language status of } \\
\text { Hokkien language as the mother tongue as well as the identity of } \\
\text { Hokkien ethnic, the pride of the culture, and the solidary among } \\
\text { Hokkien speakers. }\end{array}$ \\
\hline
\end{tabular}

Corresponding Author: Linda Wijaya, English Applied Linguistic Study Program, Postgraduate School, State University of Medan, E-mail: huangxiurung@gmail.com

\section{Introducation}

\subsection{The Background}

Language is one of the major determinants in indicating one's background as well as origin. It has also been considered as a vital tool for communicating and socializing with people (Schieffelin \& Ochs, 1986). It is used by people regardless of age, gender and races. Even the disable people who are mute and deaf possessed their own language which is known as the sign language. Language can be acquired, shifted and also loss due to many reasons and one of them is migration to a new place (Song, 2010). Most people acquired, shifted or loss their native languages when they moved to a new place as they tried to adapt with the new environment 
and connect with the local people (Tseng\& Fuligni, 2000). In order to be accepted by the major population in a society, some tend to perceive their native language negatively and neglect the importance of preserving the origin language inherited from their ancestors. Hence, it can be seen that one's language may shift to other language as a result of migration to a new surrounding that is different from the ordinary environment.

According to Fishman (1972), the language used in the communities that apply more than one language depends greatly on two main indicators which are change or stability in the actual language usage. Nevertheless, the speech communities that employ more than one language normally categorized the various languages under low or high variety language (Ferguson, 1959). The high variety languages are the languages used by majority of the population whereas the low variety languages will be the ones used by the minority groups. Based on Giles (1977) and Kibrik (1991), the high variety language typically possessed a greater opportunity to be the language used at home.

Furthermore, languages do not take place in vacuum, on the contrary, they are used in communities which are also in constant contact and relation with each other. They are almost never stable and affected by each other; thus, some influences as well as changes might occur in between those languages. Moreover, some languages become stronger while some languages diminish or even die due to various sociological reasons according to Baugh (2011). Correspondingly, in most situations this change takes place as a result of the effect majority language towards the minority language. Various factors may affect this change, thus a wide sociolinguistic analysis is required to understand what happens and why it happens.

Every ethnic has its different and unique indigenous language that is spoken by speakers having the same identity. The Indonesian Chinese (Tionghoa) as one of ethnic groups in North Sumatra attempt to survive amongst the heterogeneity of ethnics coming not only from North Sumatra province but also other areas in Indonesia, such as West Sumatra and Java. Many ethnics are mistaking of thinking that Indonesian Chinese speak Mandarin language; however, the Indonesian Chinese contain of numerous tribes that there is an assimilation of the Chinese in North Sumatra, such as Hakka (Khek), Hokkien, Konghu, Teochew, Hailohong and Henghwa tribes. Out of those, the Hokkien populate the most and therefore many Indonesian Chinese are accustomed to speaking Hokkien language instead of Mandarin language.

Growing up as a Chinese in Medan, Hokkien played a very big part in almost everything as it is technically our first language. My teachers and classmates from kindergarten all the way through high school were mostly Chinese, and Hokkien was often the language we use to ask questions, play and talk with our friends. Also, the food shops we frequent, stores we go to - many are owned by Chinese, and Hokkien was, and is very much still the language we use to communicate.

The prominence of Hokkien in Medan can be contributed to the fact that teaching and learning Mandarin was banned for about 35 years throughout Indonesia from the 1960s to the early 2000s. However, Hokkien survived the ban in Medan, because it is a spoken language and there were not as many eyes watching over Medan at that time as compared to other central cities, such as Jakarta, Bandung, or Surabaya, where both Mandarin and other Chinese languages failed to remain.

When talking about Medan Hokkien, it does not include just the city of Medan. Other North Sumatran cities surrounding Medan with significant Chinese communities also speak the language, including Chinese people from the cities of Binjai, Lubuk Pakam, Tanjung Balai, Pematangsiantar, and many more despite what tribes they belong to. People dealing in local trades, businesses, schools use Hokkien predominantly and they switch to using Indonesian only when necessary.

In modern society, increasing globalization has a tremendous impact on indigenous language loss around the world. Languages that are commonly used in business throughout the world such as English and Mandarin Chinese have trickled into remote locations, thus competing with smaller, local languages according to Rymer (2012). It happens to the Hokkien community in North Sumatra; people, especially children, are taught to speak English or some Mandarin language. The researcher found this phenomena was caused by family. Parents start to believe that in order to have better job prospects, children must be solely fluent in the dominant language rather than indigenous language. In fact, according to Perlin $(2014$, p.71) states that the languages that are most likely to disappear over the next century are unknown outside their communities. It means that if a language is confined to use within a community, it truly becomes endangered according to Baines (2012).

There are growing numbers of Medan Chinese households that view Hokkien as a second-class Chinese language, and they strive to exclusively use Mandarin or English to become their perception of "elite" compared to the rest of Chinese Medanese who speak solely Hokkien. This notion has observably starting to trickle down from adults to teenagers and children.

It is Hokkien that provides the basics for Chinese Medanese to pick up Mandarin or English so much faster compared to other first - time learners. Tones, grammar, and vocabularies come very instinctively because they are similarly structures to Hokkien, one just needs to learn the "switch" and build on it to learn those languages, Mandarin or English. 
Language maintenance is important for preserving connections to the past and one's ancestors. The globalization that has changed people's mind against indigenous language led to widespread language loss. Chew (2015) states that revitalizing the languages is a step toward healing the historical trauma and ensuring survival of people's lives. The Indonesian Chinese in Medan speak Hokkien in their ordinary interaction or communication; some have forgotten and abandoned it.

Historically, this language was once forbidden by the regime of the New Order for the Chinese people were accused of being involved in the Communist Party coupe de tat - the 1965's terror that brought Indonesia into practically the psychological war between West and East alignment, the truth about which has not yet been fully proven. That tragic incident put the Chinese into such a fragile position that many of them were massacred. Whether it happened long time ago or happens in the present day, the Hokkien language is gradually facing extinction. People's mindset is influenced either by the historical event or modern globalization. In addition to that, Meza (2015) states that learning one's heritage language is an important factor in reclaiming ties to the past and to one's cultural roots. Indigenous language should not be vanished; instead of that it should be preserved in order to show the importance of language that shows identity and symbolizes the culture of one's ethnic.

Language maintenance is seen to be applicable to preserve the existence of Hokkien language among its speakers. Hokkien native speakers should be conscious and realize that mother tongue or the so-called indigenous language is needed to teach and practice especially for children so children will not feel ashamed of their own language.

The research finding is tightly relevant to the previous study done by Indra Hartoyo who is the lecturer of FBS UNIMED that Hokkien language is required in the field of work. However, the study conducted was inadequate and the finding was too limit that the Hokkien language is maintained in the field of work. The researcher found that language is very vital to be taught in the early stage of language acquisition regardless of how sophisticated and advanced the development of the technology is. Hokkien language should be maintained so that the Chinese generation will be perpetuated. The reason of conducting of this study is that the researcher felt that Hokkien language is functioned as communicative or spoken language; it does not possess any grammatical or structural sentences. It is basically used to communicate with one another to show the identity, culture or custom and more importantly to reveal intimacy among others.

The researchers has also observed that there are some families taking efforts in maintaining their ethnic languages. This phenomenon makes the researchers feel that it is necessary to describe this phenomenon and to find out the factors influencing the language maintenance in society especially in the families.

In a nutshell, it cannot be denied that language is important in socializing with others. Through the variety of studies that have been conducted by past researchers, it can be seen that language may be maintained due to many reasons and some of them are due to language attitude and language practices. Hence, the study has been made to see how to maintain Hokkien language among its speakers in Medan. The findings will also be significant to both researchers and practitioners in the future.

\subsection{Research Questions}

Besides that, the study attempts to answer the following questions:

1. What maintenance do the Hokkien speakers make to use their language in Medan?

2. How do the Hokkien speakers maintain their language?

3. Why do Hokkien speakers maintain their language in the way they do?

It is hoped that this study is significantly beneficial for either theoretical or practical aspects. Theoretically, the finding of this research will be useful for the next researcher who will run further research dealing with language maintenance particularly in discussing about indigenous language or mother tongue. Practically, it is hoped that this study is useful for all Hokkien speakers to realize that it is important to maintain their language in order to keep the existence of their ethnic groups.

\section{Method}

This study deals with maintenance of Hokkien language by its speaker in Medan. It was conducted at family household in which the family contained of grandparents, parents and children and was held on October 7 , 2019. The data of this study were the data taken after the interview with Hokkien language speakers and the data during observation. The source of the data were nine respondents for one interview session. They were selected based on the family background, such as gender, age and occupation. This study was conducted in qualitative research design. According to Guba and Wolf in Bogdan \& Biklen (1982) qualitative research is called naturalistic because the researcher observes the places or events where he or she is interested naturally and the data are collected by interview, questionnaire and observation. Bogdan \& Biklen (1982) state that qualitative research is descriptive. The data collected are in the form of words. The data include observation sheets and interview. This study describe what maintainance Hokkien language speaker make to use the 
Hokkien language, the process Hokkien speakers maintain their language and the reasons Hokkien speakers maintain their language.

To begin with, the researcher collected the data which were transcripts of interview by Hokkien native speakers in Medan. Besides doing interview, the researcher concerned to the reflective observation which had interpretation or opinion of the researcher. After the data collection, the researcher condensed the data. From the data, the researcher selected them to answer the research question about the language maintenance occurred, the process and the reasons of Hokkien language maintenance. Then, it was focused to the interview of the subjects. The next step was to simplify the data. It means the data were arranged to be classified to each language maintenance occurred. Then, the data were abstracted and transformed into hypothesis in answering each of the research problem.

\section{Results}

Based on data analysis, there are 6 findings about the language maintenance of Hokkien speakers in Medan:

\subsection{Hokkien language is partially used by Hokkien speakers in Medan}

According to Merriem Webster dictionary, partial means not a whole or not total. Partial use means that the language is used based on certain situation, whether it is spoken to only Hokkien speakers or non Hokkien speakers. This partial use of Hokkien language can be proven by following statements:
Pertama, peneliti menanyakan bahasa keseharian dari bibi Yanti dalam berkomunikasi sehari-hari, jadi bibi menjawab: "Ya, selama ini saya juga menggunakan bahasa Hokkien, tapi kalau perlu pakai bahasa Indonesia, maka pakailah bahasa Indonesia, tapi dari kecil memang sudah pakai bahasa Hokkien. Tergantung situasi juga, kalau ketemu sesama suku Hokkien, maka bibi pun menggunakan bahasa Hokkien. Bibi juga menambahkan bahwa dia menggunakan bahasa Hokkien kepada orang tua, rekan kerja, dan kalau bukan berhadapan dengan sesama suku kayak karyawan $O B$ di kantor, ya pakai bahasa Indonesia, tapi keseringan menggunakan bahasa Hokkien itu lebih tinggi. (Yanti Chow)

This data can be called as partial use of Hokkien language because the informant uses another language which is Indonesian language according to the situation that she meets, so not in every circumstance, the informant uses Hokkien language. Besides that, the informant stated the data confidently.

The above data is strengthened by the data stated by the second and third informant:

\section{Saya menggunakan bahasa Hokkien saat berkomunikasi dengan teman-teman atau sama orang yang bisa mengerti bahasa Hokkien. (Melisa)}

\section{Ya, pakai bahasa Hokkien juga, kecuali kalau kita lagi kumpul dan ada satu teman kita yang bukan orang Hokkien yang tidak tahu berbahasa Hokkien, otomatis kita memakai bahasa Indonesia. (Nelly)}

Based on the statement above, the researcher has drawn conclusion that Hokkien speakers still maintain the language when they meet with their own ethnics. Basically, it is considered as situational language process. Besides that, living in Indonesia which has various background, culture and ethnics determines people to utter their language to whom they make conversation. This is proven by Nelly's statement that, kecuali kalau kita lagi kumpul dan ada satu teman kita yang bukan orang Hokkien yang tidak tahu berbahasa Hokkien, otomatis kita memakai bahasa Indonesia. Indonesian language is used in formal situation in order to avoid gap between native speakers and non-native speakers. Hokkien speakers also appreciate those who are nonnative speakers. This positive attitude is a key factor in the perception of a language's ethnolinguistic vitality, which in turn is a good predictor of language maintenance.

\subsection{Hokkien language is spoken to family}

Out of numerous definitions of family, the researcher chose the definition that suited to her research. According to Merriem Webster dictionary, language used within family is a group of related languages descended from a single ancestral language. Shortly to say, Hokkien language comes from Hokkien's ancestors which is still preserved until now by its speakers that residue in Medan. Talking about Medan, Medan is populated by the Indonesian Chinese and most of them are Hokkien ethnics. So, when the Chinese 
gather in certain event, especially family gathering, they will use Hokkien language as general. This can be proven by Nelly's statement: "Saya menggunakan bahasa Hokkien saat berkumpul bersama keluarga, ataupun teman yang bersuku sama."

The informant stated the data positively while discussing about family. She responded with full confidence that she would apply Hokkien language in family gathering. Besides family, friends of the same ethnics are also considered as having close relationship. This statement can be proven by Yanti's statement: "Biasanya kalau kumpul keluarga, kumpul sama teman, lebih sering menggunakan bahasa Hokkien karena dari memang kecil sudah diajarkan bahasa Hokkien. It means to say that friends who are quite like acquaintance or friends who have been known since in the early age. It can also be strengthened by another informant, Melisa: "Saya menggunakan bahasa Hokkien saat berkomunikasi dengan teman-teman atau sama orang yang bisa mengerti bahasa Hokkien.

In conclusion, Hokkien speakers still maintain their ancestral language by using it in family. In addition, Hokkien speakers, in socializing with friends, also use Hokkien language.

\section{3 Hokkien language is no longer taught to children}

This is a kind of phenomena that has induced the researcher to explore this study. The researcher is eager to show the opposite of language maintenance which is that language can become extinct if it is no longer taught to younger generation, in this case, children. Human beings live to continue their descent, and so does language. It means to say that language evolves at the same time human beings grow up. So, the researcher is sure that language is inherited and acquired during childhood.

Considering technology is getting more sophisticated, human life is influenced from time to time. This has made human beings think more effectively, efficiently and practically. The most drastic effect in educational field is the emergence of international schools in Medan. Parents are clearly ensured that their children should get better future, so they tend to register their children to attend those schools. From this case, young kids are taught to speak English for parents think that English language is far more important than indigenous language. This is proven by Melisa's statement as following:

\section{"Nggak, kalau biasanya berkomunikasi dengan anak-anak, saya menggunakan bahasa Mandarin atau Inggris. Karena kalau bahasa Hokkien itu gampang dipelajari, jadi kalau di rumah biasa sama anak-anak memakai bahasa Mandarin saja atau bahasa Inggris.”}

From the above data, it can be said that language maintenance owned by young native speakers is categorized as weak effort. The informant is seen to think that Hokkien language is too simple and it can still be taught later when the children get mature. This can be proven by the informant's statement: "Biasa saja sih, karena bahasa Hokkien sangat sederhana banget (Melisa)." The other language, for instance English, which has higher impact towards young generation is a must to be learnt as it is more complicated and difficult. Not only English, but the informant also speaks Mandarin to the children. According to the researcher, Hokkien language that is spoken in Medan is extremely easy to understand because some of the terminologies have been shifted to Indonesian language. As the Indonesian Chinese has been living in Indonesia, their mother tongue which is Hokkien language is rather influenced. Needless to say, the difference in demographical area also distinguishes Hokkien language used in Bagan Si Api-api and Hokkien language used in Medan as it is clearly stated by Yanti's statement:

\section{Beliau menjelaskan dan juga menambahkan memang benar bahasa Hokkien yang digunakan di Bagan Si Api-api jelas berbeda dengan yang di Medan, bahkan saat pertama kali menetap di medan, beliau belum begitu beradaptasi dengan logat yang digunakan oleh orang Medan ini, kadang-kadang orang medan ini juga mencampur bahasanya dengan bahasa Indonesia sehingga menimbulkan kebingungan, tapi itu semua hanya bersifat sementara, perlahan-lahan mulai juga terbiasa dengan komunikasi yang menggunakan bahasa Hokkien seperti itu.}

The Hokkien language used in Bagan Si Api - api is very distinct from that used in Medan, whether it is from accent and also some terminologies that have been swifted to Indonesian language. It needs adaptation for the informant to be familiar with Hokkien language spoken in Medan. The informant also adds that Hokkien language used in her area is more authentic than the one used in Medan as in the following statement:

SALTeL Vol. 3, No. 1, 2020: 18-27 
"Selain itu, beliau juga menambahkan bahasa Hokkien yang ada di Bagan Si Api-api itu lebih kental dan lebih menyerupai ke bahasa Hokkien klasik/kuno. Berbeda dengan yang di Medan dan logatnya juga tidak sama."

"Dan ketika berbicara kepada anak-anak, apakah bibi juga menggunakan bahasa Hokkien? Beliau menjawab: "Ya. Saya jelas bahasa Hokkien karena bahasa tersebut kan berasal dari orang tua kita, nenek kakek semua bisa paham atau dengar bahasa tersebut, kalau pakai bahasa lain seperti bahasa Inggris dan Mandarin, takutnya tidak paham."

"Pertama, kita harus ajarkan bahasa Hokkien mulai dari baby sampai usia dewasa, mereka sudah fasih berbahasa Hokkien, karena bahasa Hokkien adalah bahasa nasional kita, jadi pertama di dalam keluarga, kita harus bisa bahasa Hokkien, dari keluarga baru bisa ke teman, setelah itu baru ke kalangan luar. Intinya lebih banyak ke bahasa Hokkien dulu lah.”

From this phenomena, the researcher wants to show that language maintenance owned by old native speaker is stronger. It is strengthened by the following statement:

“jadi nanti kalau anak sudah dewasa, dia kan dapat sekolah, setidaknya ada lah pengajaran bahasa Inggris dan Mandarinnya, jadi saya rasa gak ada masalah sih mengenai pembelajaran kedua bahasa tersebut, secara tidak langsung kedua bahasa tersebut bisa dinomorduakan."

The informant highlights that the other languages which has more impact to human life can be put aside and later be learnt by children from school, so Hokkien language which is mother tongue should be taught to children first. The Hokkien language cannot be considered as "simple" and "easy" too, because the informant who derives from Bagan Si Api - api also needs to adjust her Hokkien language with the one spoken in Medan.

There is possibility of Hokkien language used in Medan gets less interest as the Hokkien speakers are not able to maintain its terminology. In addition, native speakers are rare to be found as has been stated by Nelly as following:

"penting, karena kita sudah hampir kehilangan sumber asli dari bahasa Hokkien ini, sehingga kadang-kadang bahasa ini harus diganti dengan bahasa lain.”

In the following statement, it shows that besides lacking of native speakers, there is an example of Hokkien language which has been altered to Indonesian language:

Sebagai tambahan, karena kurangnya penutur asli / leluhur
yang kebanyakan sudah meninggal dunia, bahasa Hokkien
dalam kosakatanya sudah memiliki banyak pergeseran,
sehingga kadang bahasa Hokkien yang ada di Medan sudah
tidak asli lagi, contoh kalimat: "kamu sudah makan belum?"
dan diterjemahkan "lu ciak liau boi"? Kata "lu” itu
merupakan serapan dari bahasa Indonesia, jadi peneliti
meyakini bahwa kata "kamu" pasti memiliki kosakata
bahasa Hokkien sendiri.

From the statement above, the researcher attempts to find the lost terminology which is "kamu". Actually, Hokkien language does have its own terminology according to the native speakers. The following statement can prove the existence of its terminology:

"Seperti yang tadi dikatakan, kosakata bahasa Hokkien "kamu” itu jelas ada, itu pelafalannya "de" (huruf d nya ditekan), jadinya seharusnya bukan diterjemahkan “lu”. Dan jika kalimat "kamu sudah makan belum? Dalam bahasa Hokkien Bagan Si Api-Api itu menjadi “de ciak pa be?”

In a nutshell, the researcher has drawn conclusion that old native speaker puts much effort to maintain the Hokkien language while the young ones tend to think lesser. In spite of that, mother tongue should be preserved for its existence, not because the Hokkien language is considered easy. Every language has its own 
features that make it unique. If the language has been swifted to another language, the researcher is completely sure that the language will gradually diminish and extinct.

\title{
3.4 Hokkien language is as a form of respect to parents or to elderly
}

As Hokkien language is rooted from ancestors, Hokkien speakers should preserve the language by keep using it as media communication. This is to show the reason to keep maintaining the language by the following statements:

\begin{abstract}
"beliau juga memaparkan alasan menggunakan bahasa Hokkien yaitu penghormatan kepada leluhur, juga penghormatan kepada orang tua karena dari kecil sudah diajarkan bahasa Hokkien jadi itu sudah turun temurun dari leluhur kita."(YC)

"Ya, karena ini bahasa kan sudah turun temurun, jadi mau tidak mau saya harus menggunakan bahasa ini, jadi memang haruslah bahasa ini saja.” (Adi)
\end{abstract}

Those statements have stated that Hokkien language is used as a form of respect towards ancestors and also towards parents as Hokkien language is inherited from ancestors. This attitude should be taught to younger ones or children so that they know how important their mother tongue is. This is to broaden their mind that Hokkien language is not basically used in conversation; more than that, it is as so called inherited language as has been stated by Evelyn's statement: "Ya, karena merupakan bahasa ibu, jadi otomatis kalau jumpa sama orang Hokkien, ya otomatis langsung keluar bahasa Hokkiennya."

Consciously, those informants states the data whole heartedly. It can be said so because Hokkien speakers while meeting with one another will automatically use Hokkien language. In conclusion, every human beings, be it ancestors or predecessors, do not know when the language is born amongst people; however, the language being heard from the very beginning is considered as mother tongue, the language which is spoken by mother and the language be considered as essential in life.

3.5 Hokkien language is as to show identity

In this case, identity is acted as a symbol. Maintaining Hokkien language does not stick to the ancestors, but it also can show the identity of Hokkien speakers as shown in the following statements:

\author{
“Oh, jelas, jelas mereka tahu kita orang Hokkien, apakah \\ kalau berpapasan dan mendengar bahasa Hokkien, eh \\ bahasa Hokkien tuh, bahasa Hokkien, sudah tahu mereka itu \\ orang Tionghoa, so pasti jelas.” (Yanti Chow) \\ “OH, ya pasti dong, ya saat saya berbicara bahasa Hokkien, \\ kan bahasa Hokkien saya kental, jadi Nampak kalau \\ bahwasanya saya suku Hokkien.” (Adi) \\ "Ya, itu dapat menunjukkan identitas.” (Evelyn)
}

All of the statements above are stated by the informants confidently. Language not only expresses identities but also constructs them. Language and identities are interwoven and have close interrelationship. For instance, many sayings that language that people use indicates their family condition whether they come from good one or bad one. If one speaks politely, it can be said that he has a good manner or is raised by good family. Language that we carry on ourselves can express our identity, for instance, there is a striking difference between Hokkien speakers in Bagan Si Api- api and the ones in Medan. Briefly, Hokkien language can be maintained as Hokkien speakers consider Hokkien language as to express identity.

\subsection{Hokkien language is used for certain purposes.}

Purpose means the objective or intention in using language. Besides the language is functioned as media communication, it can be used as foundation for learning the Mandarin language as stated in the following:

"penting sih karena kan, kalau kita ada dialek Hokkiennya ya pasti waktu belajar Mandarin nanti yang pada umumnya digunakan oleh dunia juga lebih gampang mempelajarinya loh, daripada kita menggunakan aksen Indonesia, dan menggunakan aksen Hokkien, kalau belajar Mandarin itu lebih gampang.” (Evelyn)

Based on the above statement, the informant, Evelyn, is sure that maintaining Hokkien language can help learners to study Mandarin more easily. Moreover, Hokkien language can be used in another purpose as the following statements: 


\title{
“Tapi karena saya penjaga toko, kadang-kadang yah saat pelanggan menanyakan harga dan saya ingin bernego dengan bos saya, saya langsung merubah bahasa saya, yaitu bahasa Hokkien agar pelanggan tidak tahu harga modal kami.” (Nelly)
}

"Ya. Bahasa Hokkien merupakan bahasa penting untuk dipertahankan. Bisa dikatakan sebagai pemersatu lah. $N$ juga menambahkan bahwa ada sebuah siaran TV yaitu DAAI TV yang bisa ditonton oleh kalangan muda-mudi karena selain pemain berbicara dengan bahasa Hokkien, isi dari film tersebut kebanyakan bersifat moral yaitu harus menghormati orang tua dan juga ada terjemahan dari bahasa Hokkien yang diucapkan mereka karena bahasa Hokkien mereka berasal dari Negara Taiwan”. (Nelly)

Hokkien language can be functioned as learning media through television channel which is known as DAAI TV. In this case, DAAI TV has channeled one film which has moral lesson. It also can lead Hokkien speakers to deepen their terminologies, to improve their accent and to know the culture of Hokkien ethnic through this television channel. In conclusion, the researcher believes that DAAI TV will keep on telecasting good film to attract more Hokkien speakers, especially children to watch it.

\section{Discussion}

Based on data analysis, the researcher extends interpretation about the findings with the previous studies. Fishman (1991) said that language maintenance is an effort in keeping the language alive by using that language continually in facing the competition among other languages in society. This is in line with the findings that Hokkien language is used in family gathering, especially towards children as stated by Yanti's statement:

\begin{abstract}
"Cuman kalau kita orang Hokkien, kita memang haruslah berbahasa Hokkien, karena itu kan setidaknya kita masih menghormati dan melestarikan bahasa kita sendiri, kalangan kita sendiri, jadi pertama itu tetap / harus diajarkan bahasa Hokkien, jadi nanti kalau anak sudah dewasa, dia kan dapat sekolah, setidaknya ada lah pengajaran bahasa Inggris dan Mandarinnya."
\end{abstract}

In addition, Nahir (2003) states that language maintenance is the preservation of the use of a group's native language, as a first or even as a second language, where political, social, economic, educational, or other pressures threaten or cause (or are perceived to threaten or cause) a decline in the status of the language as a means of communication, a cultural medium, or a symbol of group or national identity. It is absolutely true that Hokkien language use declines because the number of remaining speakers or the native speakers is rare to be found. This phenomena could be proven by the loss of Hokkien terminologies although it does have its own terminologies. Also, people's mindset influences Hokkien speakers to always apply another language in communication. This will give a decline in the status of the language as a means of communication. Talking about cultural medium, according to the informant that derives from Bagan Si Api-Api, she states that the use of Hokkien language can be taken as a form of self-respect and appreciation towards the elderly. On the contrary, people use Hokkien language just because they feel comfortable or are getting to use the language with family, friends without giving much effort to keep preserving it. Crystal (2000) identifies five main reasons why languages should be protected from dying and these include: 1) preservation of our diverse traditional cultural wealth, 2) ethnic identity through language, 3) languages serving as repositories of history, 4) languages as source of human knowledge, and 5) fascinating nature of language.

\section{Conclusion}

Based on research findings, the language maintenance of Hokkien speakers between young native speakers and old native speakers is different. The former has less effort than the latter. It is aimed to describe language maintenance that occurs in society, ways and the reasons of Hokkien language maintenance. Based on the data analysis, it was found that there was a background that caused Hokkien language needed to be maintained. In this modern era, parents put less interest towards Hokkien language, so that children were no longer taught. This phenomena has triggered the researcher to explore the study. However, according to old Hokkien speakers, Hokkien language was still maintained in family. It is definitely true that parents ensure their children's education, yet in studying another language, in this case Mandarin or English language, is a second matter that is able to be learnt after mastering the first language which is Hokkien language. The process of maintaining Hokkien language is by applying it in daily communication. Besides that, children 
especially should be introduced about the importance of Hokkien language. Solidarity will remain in relationship. It is important as well that Hokkien children be taught the principle of Hokkien language in family in order to preserve Hokkien language. The reasons of Hokkien language maintenance is by evoking self-appreciation towards the language itself. By using and preserving Hokkien language, it can give Hokkien speakers a status and express identity as well as respect towards the elderly.

\section{References}

Ajzen, I. (1988). Attitudes, personality and behavior. Milton Keynes: Oxford University Press.

Awal, N. M. (2013). Maintenance of Mother Tongue: Patterns of Language Choice at the Malaysian-Thai Border. Malaysia: Elsevier Ltd.

Baker, C. (2001). Foundation of Bilingual Education and Bilingualism. Clevedon: Multilingual Matter.

Batubara, A. S. (2011). The Maintenance of Bahasa Mandailing in Tembung. English Applied Linguistic Study Program Post Graduate Program State University of Medan: Medan.

Baugh, J. (2011). Power, social diversity and language. In R. Mesthrie (Ed.), The Cambridge handbook of sociolinguistics (pp. 17-28). Cambridge: Cambridge University Press.

Bohner, G., and M. Wanke. (2002). Attitudes and attitude change. Hove: Pschology Press.

Elmes, D. (2013). The Relationship between Language and Culture. National Institute of Fitness and Sports in Kanoya International Exchange and Language Education Center.

Ferguson, C. (1959) Diglossia. Word, 15, 325-340.

Fishman, J.A. (1972) Language maintenance and language shift as a field of inquiry: Revisited. Language in Sociocultural Change. Stanford: Stanford University Press.

Fishman, J. (1972). Language in Sociocultural Change. Stanford, California: Stanford California Press.

Fishman, J. (1991). Reversing Language Shift. Clevedon: Multilingual Matters Ltd.

Garrett, P., N. Coupland, and A. Williams. (2003). Investigating language attitudes. Cardiff: University of Wales Press.

Giles, H. (1977) Language, Ethnicity and Intergroup Relations. London: Academic Press.

Hardjanto, T.D. (1997). Language Maintenance and Language Shift with Particular Reference to the Spread of English. Humaniora.

Holmes, J. (1992). An Introduction to Sociolinguistics ( $1^{\text {st }}$ ed). Pearson Education Limited.

Holmes, J. (2001). An Introduction to Sociolinguistics ( $\left.2^{\text {nd }} \mathrm{ed}\right)$. London: Longman.

Holmes, J. (2013). An Introduction to Sociolinguistics. London: Routledge.

Kibrik, A.E. (1991) The problems of endangered languages in the USSR. In R.H. Robins and E.M. Uhlenbeck (eds) Endangered Languages (pp. 257-273). Oxford: Berg Publishers.

Kobul, M.K. (2016). Language Shift and Maintenance in a Diglossia Environment with its Educational Implications: A Case Study. Journal of Narrative and Language Studies, 4 (7), 1-16.

Lestari, N.S. (2016). The Maintenance of Bahasa Banten in Langkat,Medan. Universitas Negeri Medan.

Lincoln, Y. S., \& Guba, E. G. (1985). Naturalistic inquiry. Newbury Park, CA: Sage Publications.

Mahadi, T.S. \& S. M. Jafari. (2012). Language and Culture. International Journal of Humanities and Social Science, 2(17)

Miles, M. B. \& A. Michael Huberman. (1994). Qualitative Data Analysis. London: Sage Publications Ltd.

Myers-Scotton. (2006). Multiple Voices: An Introduction to Bilingualism. Blackwell.

Ochs, E. (1993). Constructing social identity: A language socialization perspective. Research on language and Social Interaction, 26(3), 287-306.

Oppenheim, A. (1992). Questionnaire design, interviewing and attitude measurement. London: Continuum. 
Paciotto, C. (2013). A Case Study of A Minority Language Maintenance Program in Italy: Students' and Teachers' Perspectives on the Slovene-Medium School Network. USA: Elsevier Ltd.

Saragih, A. (2010). Revitalisasi Bahasa Daerah. An Article on February 22, 2010, issued in Harian Waspada. Page C.6 Medan: Harian Waspada

Sari, R. A. (2015). Malay Language Maintenance Among the Speakers in Desa Baru Batang Kuis. Medan: Universitas Negeri Medan.

Schieffelin, B. B., \& Ochs, E. (1986). Language socialization. Annual review of anthropology, 163-191.

Song, J. (2010). Language ideology and identity in transnational space: Globalization, migration, and bilingualism among Korean families in the USA. International Journal of Bilingual Education and Bilingualism, 13(1), 23-42.

Spolsky, B. 1998. Sociolinguistics. Oxford University Press.

Tseng, V., \& Fuligni, A. J. (2000). Parent-Adolescent Language Use and Relationships Among Immigrant Families With East Asian, Filipino, and Latin American Backgrounds. Journal of Marriage and Family, 62(2), 465-476. 